International Research Journal of Microbiology (IRJM) (ISSN: 2141-5463) Vol. 7(1) pp. 001-009, February, 2018

Available online http://www.interesjournals.org/IRJM

DOI: http:/dx.doi.org/10.14303/irjm.2017.020

Copyright (c) 2018 International Research Journals

Full Length Research Paper

\title{
Screening of secondary metabolite from waterfall and marine bacteria as biocontrol agent
}

\author{
*Stella Magdalena and Clarisa Marlim \\ Atma Jaya Catholic University of Indonesia \\ "Corresponding Author's Email: stella.magdalena@atmajaya.ac.id
}

\begin{abstract}
Biocontrol agent often used to reduce sources of disease, such as bacteria, fungi, and mosquito. Emergence of antibiotic-resistant bacteria and fungi are increasing due to excessive used of antimicrobial substances. Chemical substances used to kill mosquito larvae in water environment might also be dangerous for human and environment. Hence, a biocontrol agent is required to be safe and effective. The purpose of this study is to discover bacteria from waterfall and marine water which has a good potential as biocontrol agent. Four waterfall bacteria (S 1.1, S 2.1, S 3.1, and S 3.2) and three marine bacteria (A 1.1, A 1.2, and PA 1.3C) were proved to have antifungal activity towards pathogenic fungal. PA 1.3A was the only marine bacteria which proved to have antimicrobial activity towards Escherichia coli and Streptococcus agalactiae. Extraction of antimicrobial substance using several solvents resulted in larger clear zone diameter and inhibition of other bacteria, such as Bacillus licheniformis and Staphylococcus aureus. Extracted antimicrobial substance of PA 1.3A was also proved to be non toxic towards Aedes aegypti larvae through larvicidal assay and mammals through brine shrimp lethality assay $\left(\mathrm{LC}_{50}>1000 \mu \mathrm{g} / \mathrm{mL}\right)$.
\end{abstract}

Keywords: Marine bacteria, Waterfall, Antimicrobial, Biocontrol agent, Brine shrimp.

\section{INTRODUCTION}

Biocontrol agent utilize natural resources to reduce source of disease. Therefore, it considered to be less harmful towards human and environment (Cook, 1988). Chemical agent might proved to be more effective than biocontrol agent, but for environment biocontrol agent was proved to be more safe, stable, and long-lasting (Sharma et al., 2013). Surfactin produced by Bacillus subtilis is one of example of biocontrol agent which is derived from bacteria (Plaza et al., 2013).

Antifungal agent is used to inhibit or kill pathogenic fungi. Usually antifungal agent works by inhibiting fungal cell wall component production, such as chitin and glucan, inhibiting protein, RNA, and DNA synthesis, also interfering with pyrimidine metabolism. Example of antifungal agents are 5-fluorocytosine which inhibit Candida and Cryptococcus neoformans through protein synthesis disruption and echinocandines which inhibit Aspergillus through inhibition of $\beta$-glucan synthesis. Nowadays, antifungal-resistance fungi is emerging through various mechanisms such as, mutation and reduce uptake of antifungal agent (Ghannoum and Rice, 1999).

Antibacterial agent is used to inhiit or kill pathogenic bacteria, usually it works through disruption of bacterial cell wall formation or inhibiting DNA synthesis. Antibacterial agent might derived synthetically such as fluoroquinolone and nalidixic acid (Soni, 2012) or from natural resources such as Bacillus subtilis bacteria which produced bacteriocin (Joseph et al., 2013) and fungi Penicillium rubens which produced penicillin (Houbraken et al., 2011).

Mosquitoes are known as disease-transmitter, such as Aedes aegypti and Anopheles gambiae that transmitted malaria disease (Derua et al., 2012). Generally, chemical substance like pyrethroids and carbamate are used to kill mosquito, but those substances are harmful towards other insects.

Moreover, due to modification of acetylcholinesterase, 
002 Int. Res. J. Microbiol.

mosquitoes can be resistance towards those chemical substances (Darriet et al., 2005).

Brine shrimp (Artemia sp.) is a mammalian model used in toxicity preliminary assessment. It is commonly used due to simplicity, inexpensive, rapid, and only small amount of substance is required (Ajoy and Padma, 2013; Olowa and Nuneza, 2013). Drawbacks of brine shrimp usage is that result might effected by solvents used (Wu, 2014).

Previous study done by Jeganatan et al. (2013) proved that bacteria isolated from marine environment (Alteromonas, Bacillus, Marinobacter) were able to inhibit pathogenic bacteria such as Escherichia coli and Staphylococcus aureus. Gohel et al. (2004) also proved that some marine bacteria from Bhavnagar (India) were able to produce chitinase which inhibit growth of pathogenic fungi such as Fusarium. Marine bacteria also can be used as biocontrol agent towards mosquitoes, as proved by Mani et al. (2015). Hence, it can be concluded that bacteria derived from aquatic environment might be useful as biocontrol agent.

\section{MATERIALS AND METHODS}

\section{Bacteria isolation from waterfall and marine samples.}

Water sample were obtained from overhang parts of waterfall and $300 \mathrm{~m}$ range from seashore (Table 1). Each sample were diluted and spreaded into Nutrient Agar (NA) (Oxoid) for waterfall sample (Odeyemi et al., 2013) and Marine Agar (MA) (Difco) for marine sample (Jeganathan et al., 2013). All media were incubated at $28^{\circ} \mathrm{C}$ overnight and different colonies were picked.

\section{Antifungal Assay}

Antifungal assay were done with two different methods, agar plug method and disk diffusion method. Pathogenic fungi used are Aspergillus sp., Fusarium sp., and Penicillium sp. Agar plug method was done based on Abla et al. (2015). Pathogenic fungi were grown in Potato Dextrose Agar (PDA) (Oxoid) supplemented with chloramphenicol (Kimia Farma) at $30^{\circ} \mathrm{C}$ for 7 days. Meanwhile, bacterial isolates were grown in PDA medium (without chloramphenicol) at $28^{\circ} \mathrm{C}$ for 48 hours. Each $4 \mathrm{~mm}$ plug of pathogenic fungi was put in the middle of media with grown bacterial isolates. All media were incubated at $30^{\circ} \mathrm{C}$ for 7 days to observed fungal growth inhibition.

Disk diffusion method was done with modification method according to Nweze et al. (2010). Pathogenic fungi were grown in Potato Dextrose Broth (PDB) (Pronadisa) medium supplemented with chloramphenicol at $30^{\circ} \mathrm{C}$ for 7 days. Bacterial isolates were grown in Nutrient Broth (NB) (Oxoid) medium (for waterfall bacteria), Sea Water Complete (SWC) (bacteriological peptone (Oxoid) $5 \mathrm{~g} / \mathrm{L}$; yeast extract (Oxoid) $1 \mathrm{~g} / \mathrm{L}$; glycerol $85 \%$ (Merck) $3 \mathrm{~mL} / \mathrm{L} ; 3 \% \mathrm{NaCl}$ (Oxoid) solution $\mathrm{v} / \mathrm{v})$ medium (marine bacteria), and Brain Heart Infusion Broth (BHIB) (Oxoid) medium (waterfall and marine bacteria) at $28^{\circ} \mathrm{C}$ for 48 hours. Bacteria supernatant were obtaine by centrifugating culture isolate twice at 13,684 $\times g$ (Thermo Scientific) for 10 minutes. Then, sterile cotton swab dipped in each pathogenic fungi was streaked to MHA medium. For positive control, $10 \mu \mathrm{L}$ of Ketoconazole $(1 \mathrm{mg} / \mathrm{mL})$ (Kimia Farma) and Griseofluvin $(1 \mathrm{mg} / \mathrm{mL})$ (Darya-Varia) were inserted into blank discs. For negative control, control well was filled with sterile NB, SWC, and BHIB medium. All plates were incubated at $30^{\circ} \mathrm{C}$ for 7 days. Each treatment was repeated twice.

\section{Antibacterial Assay}

Antibacterial assay was done using well diffusion method which modified from method based on Pundir et al. (2013). Test bacteria used were grown in Luria Broth (LB) ( $\mathrm{NaCl}$ (Oxoid) $5 \mathrm{~g} / \mathrm{L}$, yeast extract (Oxoid) $5 \mathrm{~g} / \mathrm{L}$, tryptone (Oxoid) $10 \mathrm{~g} / \mathrm{L}$ ) at $37^{\circ} \mathrm{C}$ (Acinetobacter baumannii ATCC 19606, Escherichia coli ATCC 4157, Pseudomonas aeruginosa KCTC 1637, Salmonella enterica ATCC 51741, Staphylococcus aureus ATCC 25923, Streptococcus agalactiae BAA-611), meanwhile Bacillus licheniformis ATCC 12759 and Burkholderia cepacia ATCC 25416 were grown in LB medium at $30^{\circ} \mathrm{C}$ until the absorbance value reach 0.132 at $\lambda=600 \mathrm{~nm}$ (McFarland 0.5 ). Each isolate was grown in NB medium (waterfall isolates) and SWC medium (marine isolates) at $28^{\circ} \mathrm{C}$ for 48 hours. Isolate suspension was centrifugated twice at $13,684 \mathrm{xg}$ (Thermo Scientific) for 10 minutes to obtained crude extract.

Each test bacteria suspension was spotted and streaked on Mueller-Hinton Agar (MHA) (Oxoid). $4 \mathrm{~mm}$ well was made using cork borer. Antibiotic discs of nalidixic acid (30 $\mu \mathrm{g} / \mathrm{mL})$ (BBL) and trimethoprimsulfamethoxazole $(25 \mu \mathrm{g} / \mathrm{mL}$ ) (Oxoid) were used as positive control, meanwhile sterile NB and SWC medium were used as negative control. $20 \mu \mathrm{L}$ of crude extract was loaded into each well. Plates were incubated at optimum temperature of each test bacteria. Each treatment was repeated twice.

\section{Extraction of Antimicrobial Substances}

Solvents used for extraction of antimicrobial substances were chloroform (Merck) and dichloromethane (Merck). Positive bacteria isolate was grown in SWC medium for 48 hours and measured until the absorbance value reach 0.132 at $600 \mathrm{~nm} .25 \mathrm{~mL}$ of isolate was moved to $1 \mathrm{~L}$ sterile SWC medium and incubated for 48 hours. Isolate suspension was centrifugated twice at $10,016 \times \mathrm{g}$ 
Table 1 Waterfall and Marine Samples Sources

\begin{tabular}{lcccc}
\hline Sample & Sources & Location & Isolates Code & Number of Isolates \\
\hline Waterfall & Mata Air Darmaloka (1 ${ }^{\text {st }}$ stage) & Kuningan, West Java & S & 10 \\
& Mata Air Darmaloka ( $7^{\text {th }}$ stage) & Kuningan, West Java & SN & 8 \\
& Curug Bibijilan & Sukabumi, West Java & CB & 6 \\
Curug Cikahuripan, & Bandung, West Java & AN & 2 \\
Marine & Mata Air Sawer Rahmat & Kuningan, Cirebon, Jawa Barat & SC & 12 \\
& Pramuka Island & Kepulauan Seribu, DKI Jakarta & N & 10 \\
& Perawan Beach & Kepulauan Seribu, DKI Jakarta & V & 14 \\
& Tanjung Pasir Beach & Kepulauan Seribu, DKI Jakarta & A & 2 \\
Bunaken Sea & Manado, North Sulawesi & B & 4 \\
& Padang-Padang Beach & KS & 2 \\
Matras Beach & Bangka Island, Bangka Belitung & WM & 4 \\
Ketawai Beach & Bangka Island, Bangka Belitung & WK & 5 \\
Rambak Beach & Bangka Island, Bangka Belitung & WR & 2 \\
Putri Beach & Kepulauan Seribu, DKI Jakarta & LP & 4 \\
Air Island & Kepulauan Seribu, DKI Jakarta & PA & 6 \\
\hline
\end{tabular}

(Thermo Scientific) for 10 minutes. Separation of organic phase was conducted using separating funnel with 1:1 $(\mathrm{v} / \mathrm{v})$ ratio of isolate supernatant and solvent. Rotary evaporator was used to obtained crude extract from organic phase at $50^{\circ} \mathrm{C}$. Crude extract was air dried overnight (Shetty et al., 2014) and diluted into $750 \mu \mathrm{L}$ phosphate buffered saline (PBS) ( $\mathrm{NaCl}$ (Oxoid) 8g/L, KCl (Merck) $0.2 \mathrm{~g} / \mathrm{L}, \mathrm{Na}_{2} \mathrm{HPO}_{4}$ (Merck) $1.44 \mathrm{~g} / \mathrm{L}, \mathrm{KH}_{2} \mathrm{PO}_{4}$ (Merck) $0.24 \mathrm{~g} / \mathrm{L}$ ). Antibacterial activity of crude extract towards pathogenic bacteria was tested again using well diffusion method (Pundir et al., 2013).

\section{Larvicidal Assay towards Aedes aegypti larvae.}

Larvicidal assay method was modified from Nabar and Lokegaonkar (2015). Aedes aegypti eggs were obtained from Faculty of Veterinary, Bogor Agricultural University. Eggs were submerged into $500 \mathrm{~mL}$ water for 7 days to allow the eggs hatching into larvae. Tests on each sample extracts were performed in triplicates. Each sample extract was diluted into three concentrations, 500, 1000, and $1500 \mu \mathrm{g} / \mathrm{mL}$ with addition of PBS. $0.5 \mathrm{~mL}$ of each sample dilution was added in a tube which contained 10 A. aegypti larvae in $4.5 \mathrm{~mL}$ water. Addition of $0.5 \mathrm{~mL}$ water without any sample extract, $0.5 \mathrm{~mL}$ solvent (chloroform and dichloromethane), and $0.5 \mathrm{~mL}$ supernatant of isolate was also tested as control. Each test was performed triplicates. Larvae mortality was observed after 24 and 48 hours. Mortality percentage was then counted to obtained $\mathrm{LC}_{50}$ values.

\section{Brine Shrimp Lethality Assay (BSLA)}

BSLA method was modified from Olowa and Nuneza
(2013). Cysts (brine shrimp eggs) was hatched in artificial seawater (38 grams of sea salt diluted in 1 liter of water) with continuously illuminated condition using fluorescent lamp and continuous aeration with air pump for 48 hours at room temperature. 10 nauplii (brine shrimp larvae) were added into each test tube with $4.5 \mathrm{~mL}$ of artificial seawater. $0.5 \mathrm{~mL}$ of sample extract was added. $0.5 \mathrm{~mL}$ of artificial seawater, $0.5 \mathrm{~mL}$ Phosphate Buffered Saline (PBS), $0.5 \mathrm{~mL}$ solvent (chloroform and dichloromethane), and $0.5 \mathrm{~mL}$ supernatant were added as control. Each test was performed triplicates. All test tubes was incubated under constant illumination and observed after 24 and 48 hours. Number of surviving nauplii were counted to find out mortality percentage (\%M) which then used to count $\mathrm{LC}_{50}$ values with statistical analysis. Significance differences was analyzes using ANOVA and TUKEY test. $\mathrm{LC}_{50}$ values greater than $1000 \mu \mathrm{g} / \mathrm{mL}$ is considered nontoxic, meanwhile $\mathrm{LC}_{50}$ values less than $1000 \mu \mathrm{g} / \mathrm{mL}$ is considered as toxic (Meyer et al., 1982).

\section{RESULTS}

There are total of 91 isolates derived from waterfall and marine samples. Screening of antifungal assay was done in agar plug method and disk diffusion method. Agar plug method showed only A 1.2 isolate from Tanjung Pasir beach inhibit growth of Penicillium sp. (Figure 1). Disk diffusion method showed more diverse result, such as $S$ $1.1, S 2.1, S 3.1$, and $S 3.2$ isolates from $1^{\text {st }}$ stage of Darmaloka spring water which has various inhibition capability towards all three pathogenic fungal (Table 2). Isolate PA 1.3C from Air Island and A 1.1 from Tanjung Pasir beach also showed inhibition towards Trichoderma sp. (Table 3). Isolate S 1.1 and S 3.1 showed larger 
004 Int. Res. J. Microbiol.

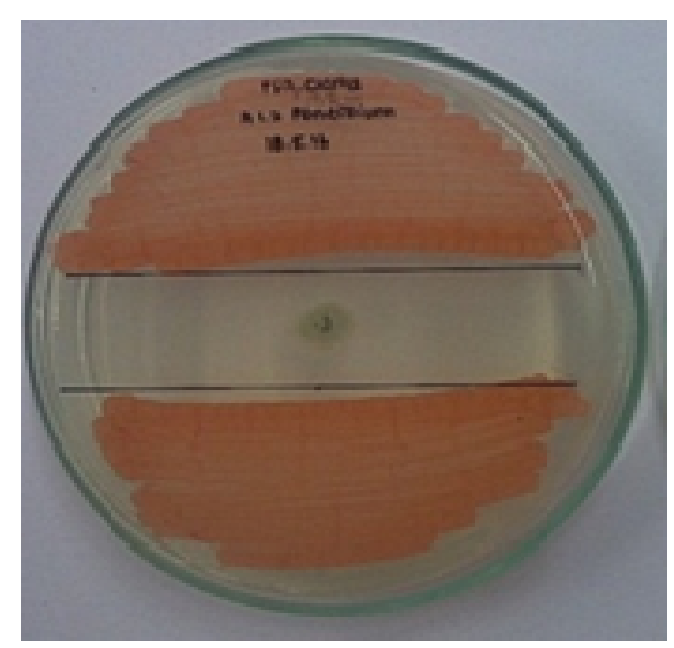

Figure 1. Antifungal activity (agar plug method) of isolate A 1.2 towards Penicillium sp.

Table 2 Antifungal activity results of waterfall isolates (disk diffusion method)

\begin{tabular}{|c|c|c|c|c|}
\hline \multirow{2}{*}{ Pathogenic Fungal } & \multirow{2}{*}{ Growth media } & \multirow{2}{*}{ Bacterial Isolates } & \multicolumn{2}{|c|}{ Diameter of Inhibition Zone (mm) } \\
\hline & & & MHA & PDA \\
\hline \multirow[t]{8}{*}{ Aspergillus sp. } & NB & $S 1.1$ & 3.00 & - \\
\hline & & S 2.1 & - & - \\
\hline & & S 3.1 & 4.00 & - \\
\hline & & S 3.2 & 3.50 & - \\
\hline & BHIB & S 1.1 & 2.25 & - \\
\hline & & S 2.1 & - & - \\
\hline & & S 3.1 & 3.75 & - \\
\hline & & S 3.2 & 1.75 & - \\
\hline \multirow[t]{8}{*}{ Trichoderma sp. } & NB & S 1.1 & 10.50 & 8.50 \\
\hline & & S 2.1 & 2.50 & - \\
\hline & & S 3.1 & 7.00 & 8.50 \\
\hline & & S 3.2 & 3.50 & \\
\hline & BHIB & S 1.1 & 7.00 & 11.50 \\
\hline & & S 2.1 & - & - \\
\hline & & S 3.1 & 6.00 & 16.00 \\
\hline & & S 3.2 & 2.25 & - \\
\hline \multirow[t]{8}{*}{ Penicillium sp. } & NB & S 1.1 & 6.50 & 6.00 \\
\hline & & S 2.1 & 1.00 & - \\
\hline & & S 3.1 & 5.50 & 6.50 \\
\hline & & S 3.2 & & \\
\hline & BHIB & S 1.1 & 4.50 & 7.00 \\
\hline & & S 2.1 & - & - \\
\hline & & S 3.1 & 4.00 & 7.00 \\
\hline & & S 3.2 & - & - \\
\hline
\end{tabular}

inhibition zone in PDA medium compared to MHA medium.

Out of 91 isolates, only one isolate derived from Air
Island (PA 1.3A) showed antibacterial activity through inhibition of Escherichia coli (Figure 3) and Streptococcus agalactiae with inhibition $8.5 \mathrm{~mm}$ and $6.5 \mathrm{~mm}$ inhibition 
Table 3. Antifungal activity results of marine isolates (disk diffusion method)

\begin{tabular}{|c|c|c|c|c|}
\hline \multirow{2}{*}{ Pathogenic Fungal } & \multirow{2}{*}{ Growth media } & \multirow{2}{*}{ Bacterial Isolates } & \multicolumn{2}{|c|}{ Diameter of Inhibition Zone ( $\mathrm{mm}$ ) } \\
\hline & & & MHA & PDA \\
\hline \multirow[t]{8}{*}{ Aspergillus sp. } & SWC & PA 1.3A & - & - \\
\hline & & PA 1.3C & - & - \\
\hline & & A 1.1 & - & - \\
\hline & & A 1.2 & - & - \\
\hline & BHIB & PA 1.3A & - & - \\
\hline & & PA $1.3 \mathrm{C}$ & - & - \\
\hline & & A 1.1 & - & - \\
\hline & & A 1.2 & - & - \\
\hline \multirow[t]{8}{*}{ Trichoderma sp. } & SWC & PA 1.3A & - & - \\
\hline & & PA $1.3 \mathrm{C}$ & 2.00 & - \\
\hline & & A 1.1 & 1.75 & - \\
\hline & & A 1.2 & - & - \\
\hline & BHIB & PA 1.3A & - & - \\
\hline & & PA $1.3 \mathrm{C}$ & 2.50 & - \\
\hline & & A 1.1 & 2.50 & - \\
\hline & & A 1.2 & - & - \\
\hline \multirow[t]{8}{*}{ Penicillium sp. } & NB & PA 1.3A & - & - \\
\hline & & PA $1.3 \mathrm{C}$ & - & - \\
\hline & & A 1.1 & - & - \\
\hline & & A 1.2 & - & - \\
\hline & BHIB & PA 1.3A & - & - \\
\hline & & PA $1.3 \mathrm{C}$ & - & - \\
\hline & & A 1.1 & - & - \\
\hline & & A 1.2 & - & - \\
\hline
\end{tabular}

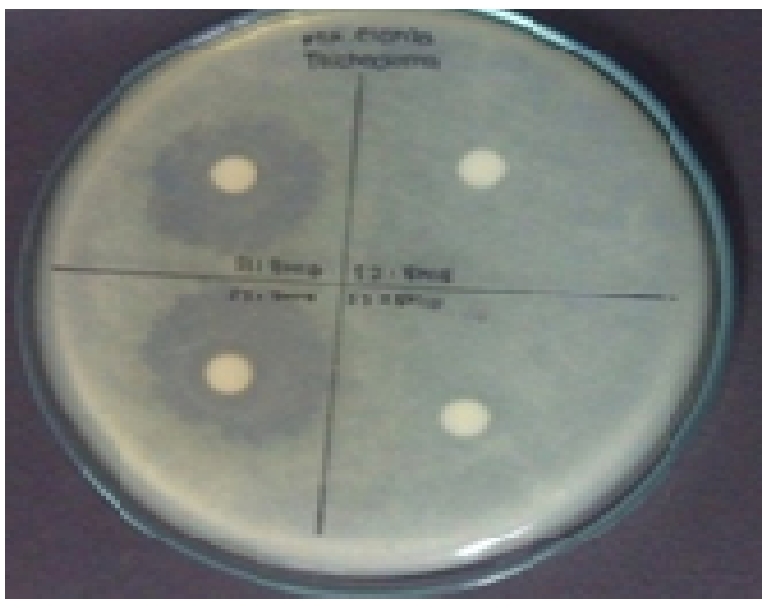

Figure 2. Antifungal activity (disk diffusion method) of S 1.1 and $S 3.1$ isolates towards Trichoderma sp. in PDA medium.

zone respectively. Extraction of antibacterial substances from PA 1.3A isolate using organic solvents showed that more bacteria were inhibited and inhibition zone diameter towards $S$. agalactiae was increased (Table 4).

Larvicidal assay results of PA 1.3A extract showed that there were no significance differences between each 
006 Int. Res. J. Microbiol.

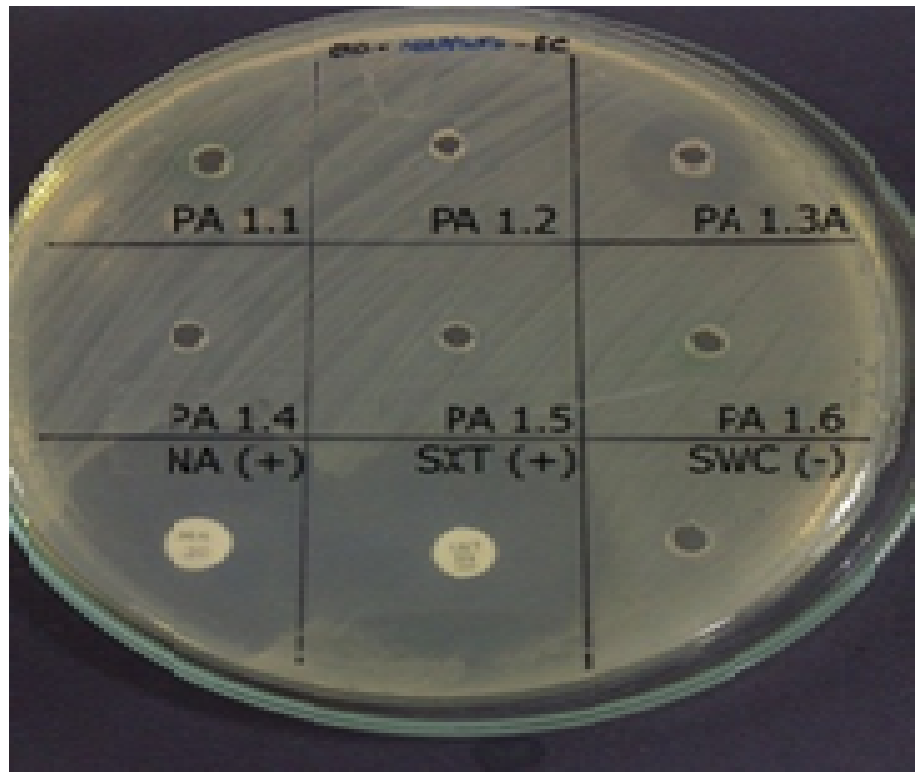

Figure 3. Antibacterial activity shown by PA $1.3 \mathrm{~A}$ isolate towards Escherichia coli. $\mathrm{PA}=$ Isolate from Air Island; $\mathrm{NA}=$ Nalidixic acid; SXT = Trimethoprim-sulfomethoxazole; SWC = Sea Water Complete broth

Table 4 Antibacterial activity results of PA 1.3A extract

\begin{tabular}{lcc}
\hline \multirow{2}{*}{ Pathogenic Bacteria } & \multicolumn{2}{c}{ Diameter of Inhibition Zone (mm) } \\
\cline { 2 - 3 } & Chloroform & Dichloromethane \\
\hline S. agalactiae & 7.50 & 8.5 \\
S. aureus & 2.25 & 5.0 \\
B. licheniformis & 0.50 & 6.0 \\
\hline
\end{tabular}

Table 5. Larvicidal assay of PA 1.3A extract

\begin{tabular}{|c|c|c|c|c|c|c|}
\hline \multirow{3}{*}{$\begin{array}{l}\text { Bacterial } \\
\text { Isolate }\end{array}$} & \multirow{3}{*}{$\begin{array}{l}\text { Period } \\
\text { (Hour) }\end{array}$} & \multirow{3}{*}{ Solvent } & \multicolumn{3}{|c|}{$\%$ Larva Mortality } & \multirow{3}{*}{$\mathrm{LC}_{50}$ Value $(\mathrm{mg} / \mathrm{L})$} \\
\hline & & & \multicolumn{3}{|c|}{ Extract Concentration $(\mu \mathrm{g} / \mathrm{mL})$} & \\
\hline & & & 500 & 1000 & 1500 & \\
\hline \multirow[t]{4}{*}{ PA 1.3A } & 24 & Chloroform & 13.3 & 13.3 & 20.0 & 1337.23 \\
\hline & & Dichloromethane & 6.7 & 20.0 & 30.0 & 0.09 \\
\hline & 48 & Chloroform & 16.7 & 23.3 & 33.3 & 0.06 \\
\hline & & Dichloromethane & 16.7 & 23.3 & 33.3 & 0.06 \\
\hline
\end{tabular}

concentrations and all of them were not toxic towards Aedes aegypti larvae (Table 5). PA 1.3A extract also proven to be non-toxic towards brine shrimp, which was shown by $\mathrm{LC}_{50}$ values that was higher than $1000 \mu \mathrm{g} / \mathrm{ml}$ (Table 6). There were no significance differences between all three concetrations towards nauplii mortality. 
Table 6. Brine shrimp lethality assay of PA 1.3A extract

\begin{tabular}{|c|c|c|c|c|c|}
\hline \multirow{3}{*}{ Bacterial Isolate } & \multirow{3}{*}{ Solvent } & & Iplii M & & \multirow{3}{*}{$\mathrm{LC}_{50}$ Value $(\mu \mathrm{g} / \mathrm{mL})$} \\
\hline & & \multicolumn{3}{|c|}{ Extract Concentration $(\mu \mathrm{g} / \mathrm{mL})$} & \\
\hline & & 500 & 1000 & 1500 & \\
\hline \multirow[t]{2}{*}{ PA 1.3A } & Chloroform & 13.3 & 23.3 & 30.0 & 40938.41 \\
\hline & Dichloromethane & 3.3 & 6.7 & 43.3 & 2444.76 \\
\hline
\end{tabular}

\section{DISCUSSION}

Antifungal assay was done in different methods in order to compared both methods. Agar plug assay results showed only one isolate which had antifungal activity towards Penicillium sp., meanwhile disk diffusion method showed diverse antifungal activity towards all three pathogenic fungal (Aspergillus sp., Trichoderma sp., Penicillium sp.). Agar plug method was often used for screening of antifungal activity because it is a simple, low-cost method, and enormous number of microorganisms can be tested (Balouiri et al., 2016). Disk diffusion method was commonly used to screen extracellular antifungal activity. Although, it also can be used to screened intracellular activity with usage of bacterial pellet (including cell). Bacterial pellet can be concentrated with centrifugating bacterial culture or reducing pressure towards culture with sonicator (Fawzy et al., 2011; Pandey and Malviya, 2014). In this study, it can be concluded that disk diffusion method was a better method to screened extracellular antifungal activity and agar plug method was better to screened intracellular antifungal activity.

Two kinds of media, Mueller-Hinton Agar (MHA) and Potato Dextrose Agar (PDA) were used in disk diffusion method. Both media were used to compared result between antifungal activity. PDA media is commonly used for disk diffusion method, but Nweze et al. (2010) proved that MHA media can also be used for disk diffusion method because it could enhance clear zone visual. MHA media was generally acceptable for antimicrobial test, because it provide stable and reproducible result (Murray and Zeitinger, 1983). In this study, more isolates shows variation of inhibition zone in MHA media, but some isolates (S 1.1 and $S$ 3.1) showed larger clear zone in PDA media.

Bacterial isolates were grown in three kinds of media, Nutrient Broth (NB) for waterfall isolates, Sea-Water Complete (SWC) for marine isolates, and Brain Heart Infusion Broth (BHIB) for both waterfall and marine isolates. Result showed that $S 1.1$ and $S 1.3$ isolates (waterfall sources) produced more antifungal substances (which can be seen with larger clear zone) in BHIB media than NB media. A 1.1 and $C$ isolates (marine sources) also produced more antifungal substances in $\mathrm{BHIB}$ media than SWC media. BHIB media is considered to be a nutrient-rich media compared to NB and SWC media (Jaradat and Bhunia, 2002). Nutrient-rich condition in BHIB might increase growth rate of bacteria which made bacteria moved to stationary phase faster and produce more secondary metabolites as antifungal substances. Similar result was also shown by Marinho et al. (2009) where BHIB supported growth of bacteriocin producing Pseudomonas putida. Another study by Elfalah et al. (2013) also showed that antimicrobial activity of actinomycetes derived from marine environment, showed highest inhibition when actinomycetes was cultured in BHIB medium.

Antibacterial activity was only shown by PA $1.3 \mathrm{~A}$ isolate towards Escherichia coli and Streptococcus agalactiae. PA $1.3 \mathrm{~A}$ extract only has antibacterial capability towards all gram positive bacteria used in this study, which were $S$. agalactiae, $S$. aureus, and $B$. licheniformis. Hence, PA1.3A extract has no activity towards $E$. coli which is a gram negative bacteria. This could happened because gram positive bacteria are commonly more sensitive towards antibacterial substances compared to gram negative (Hooper, 2001). In this study, chlorofom and dichloromethane were used because previous study done by Veronica et al. (2014) showed that antibacterial compound can be extracted using chloroform and dichloromethane. Extraction result was depended on polarity of antibacterial compound (Sunder et al., 2011). Therefore, to enhance antibacterial activity of PA 1.3 A extract different solvents can be used to explore inhibition activity towards different grams of bacteria.

Bashir et al. (2015) proved that chloroform can be used to extract antibacterial substances from ginger. Chloroform usually attract flavonoid and steroid from ginger. Chloroform could attract lipopeptides from Bacillus which inhibit growth of Saccharomyces cerevisiae and E. coli (Salam et al., 2015). Bazzaz et al. (2013) proved that dichloromethane was also used to extract antibacterial substance from Scutellaria lindbergii Rech.f. and dichloromethane attract more flavonoid but less phenolic substances. Hence, different types of solvents can be used to extract and showed diverse results.

Differences of bacterial cell wal composition in gram positive and gram negative bacteria also played an important role in susceptibilities of gram positive bacteria 
008 Int. Res. J. Microbiol.

towards antibacterial substances. Gram positive bacteria cell wall consist of thick layes of peptidoglycan and cell membrane, but without an outer membrane. Meanwhile, gram negative bacteria cell wall has an outer membrance which consists mostly lipopolysaccharide (LPS) and thin layer of peptidoglycan. This outer membrane played a crucial role as a barrier from harmful substance and stabilizing inner membrane of gram negative bacteira. Gram negative bacteira also has a transenvelope machine which act as efflux pump that expels harmful molecules such as antibiotics (Silhavy et al., 2010).

All three extract concentration $(500,1000,1500$ $\mu \mathrm{g} / \mathrm{mL}$ ) proved to be non-toxic towards $A$. aegypti larvae. $\mathrm{LC}_{50}$ value of chloroform extract was $1337.23 \mathrm{mg} / \mathrm{L}$ and $0.06 \mathrm{mg} / \mathrm{L}$ for 24 and 48 hours respectively, meanwhile for dichloromethane extract $\mathrm{LC}_{50}$ value in 24 hour was $0.09 \mathrm{mg} / \mathrm{L}$ and in 48 hours was $0.06 \mathrm{mg} / \mathrm{L}$. Therefore, it can be concluded that PA 1.3A extract concentration must be above $1500 \mu \mathrm{g} / \mathrm{mL}$ for larvicidal activity. Further study is needed to find out exact concentration of PA 1.3A extracts which has larvicidal effect (toxic towards $A$. aegypti larvae).

Mosquito will reach larval stage during one week after eggs were submerged in water. Larval stage was used in this study because at this stage larvae cannot move out from breeding sites and harmless (not acquisited with disease) (Hardin and Jackson, 2009). Eggs state was not used because eggs are usually immobile (concentrated on one area) and it will be more difficult for substances to reach the eggs. Hence, larval stage give more advantage because mosquito was spreaded in water and reachable by substances (Elimam et al., 2013).

Extract concentration can be increased by using different solvent in order to improved larvicidal ability of PA 1.3A extract. Usage of more polar substance for extraction is suggested to produce more variety of PA 1.3A extract activities (Arasu et al., 2014). Example of bacterial used as biocontrol agent was Bacillus thuringiensis subsp. israelensis (Bti) which was effective towards mosquito larvae (Priest, 1992).

According to Meyer et al. (1982), LC 50 value higher than $1000 \mu \mathrm{g} / \mathrm{mL}$ would be considered as non-toxic substances. In this study, $\mathrm{LC}_{50}$ value derived from brine shrimp lethality assay of $500-1500 \mu \mathrm{g} / \mathrm{mL}$ concentration proved that PA 1.3A extract is not-toxic for human use. If further study find out about larvicidal conentration of PA 1.3A extract, then PA 1.3A extract concentration toxicity towards brine shrimp also need to be tested.

Example of mosquito biocontrol is cyanobacteria extract which were tested towards $A$. aegypti larvae and brine shrimp. LC50 value of cyanobacteria extract towards mosquito larvae is $20.88 \mu \mathrm{g} / \mathrm{mL}$ and has a dosedependent characteristic (higher doses, higher mortality rate).

Purified substances was also not toxic towards brine shrimp. Hence, cyanobacteria has a good potential to produce non-toxic biocontrol agent (Berry, 2014).

\section{CONCLUSION}

Out of 91 isolates, four isolates from $1^{\text {st }}$ stage of Darmaloka water springs (S 1.1, S 2.1, S 3.1, S 3.2), 2 isolates from Tanjung Pasir beach (A1.1 and A 1.2), 1 isolate Air Island (PA 1.3C) were able to inhibit growth of various pathogenic fungal. One isolate (PA 1.3A) from Air Island has antibacterial ability towards Escherichia coli and Streptococcus agalactiae. PA 1.3A extract derived from extraction with chlorofom and dichloromethane was more effective towards gram positive bacteria (Bacillus licheniformis, Streptococcus agalactiae, Staphylococcus aureus).

PA 1.3A extract in three concentrations was not toxic both towards Aedes aegypti larvae and brine shrimp. Therefore, further test is still needed to find out exact concentration of PA 1.3A extract which is toxic towards $A$. aegypti larvae and safeness of extract concentration with toxicity test towards brine shrimp.

\section{ACKNOWLEDGEMENT}

This research was funded by the Atma Jaya Catholic University of Indonesia Research Centre.

\section{REFERENCES}

Abla E, Souad E, Abdelhadi H, Bazdi O, Khadija O (2015). Antagonistic activity of endophytic bacteria isolated from Mentha rotundifolia $\mathrm{L}$. IJSTR 4(12): 36-39.

Ajoy G, Padma C (2013). Brine shrimp cytotoxic activity of $50 \%$ alcoholic extract of croton bonplandianum baill. Asian J Pharm Clin Res 6(3): 40-41.

Arasu MV, Rejiniemon TS, Al-Dhabi NA,Duraipandiyan V, Agastian P, Huxley VAJ, Song CE, Choi KC (2014). In vitro antimicrobial potential of organic solvent extracts of novel actinomycetes isolated from forest soil. Afr J Biotechnol 13(18): 1891-1897.

Balouiri M, Sadiki M, Ibnsouda SK (2016). Methods for in vitro evaluating antimicrobial activity: a review. J Pharm Anal 6(2): 71-79.

Bashir SF, Gurumayum S, Kaur S (2015). In vitro antimicrobial activity and preliminary phytochemical screening of methanol, chloroform, and hot water extracts of ginger (Zingiber officinale). Asian J Pharm Clin Res 8(1): 176-180.

Bazzaz BSF, Arab A, Emami SA, Asili J, Khayyat MH, Sahebkar A (2013). Antimicrobial and antioxidant activities of methanol, dichloromethane, and ethyl acetate extracts of Scutellaria lindbergii Rech.f. Chiang Mai J Sci 40(1): 49-59.

Berry GA (2014). Mosquito larvicides from cyanobacteria [dissertation]. Florida: Department of Biological Sci., Florida Intl. Uni.

Cook RJ (1988). Biological control and holistic plant-health care in agriculture. AJAA 3(2): 51-62.

Darriet F, Duchon S, Hougard JM (2005). Spinosad: a new larvicide against insecticide-resistance mosquito larvae. J Am Mosq Control Assoc 21(4): 495 - 496.

Derua YA, Alifrangis M, Hosea KM, Meyrowitsch DW, Magesa SM, Pedersen EM, Simonsen PE (2012). Change in composition of the Anopheles gambiae complex and its possible implications for the transmission of malaria and lymphatic filariasis in north-eastern Tanzania. Malaria J. 11:188.

Elfalah HWA, Usup G, Ahmad A (2013). Anti-microbial properties of secondary metabolites of marine Gordonia tearrae extract. J Agr Sci 5(6): 94-101. 
Elimam AM, Elmalik KH, Ali FS (2009). Efficacy of leaves extract of Calotropis procera Ait. (Asclepiadaceae) in controlling Anopheles arabiensis and Culex quinquefasciatus mosquitoes. Saudi J Biol Sci 16: 95-100.

Fawzy GA, Al-Taweel AM, Melake NA (2011). In vitro antimicrobial and anti-tumor activities of intracellular and extracellular extracts of Aspergillus niger and Aspergillus flavus var. columinaris. J Pharm Sci Res 3(1): 980-987.

Ghannoum MA, Rice LB (1999). Antifungal agents: mode of action, mechanisms of resistance, and correlation of these mechanisms with bacterial resistance. Clin Microbiol Rev 12(4): 501-517.

Gohel V, Chaudhary T, Vyas P, Chhatpar HS (2004). Isolation and identification of marine chitinolytic bacteria and their potential in antifungal biocontrol. Indian J Exp Biol 42(7): 715-720.

Hardin JA, Jackson FLC (2009). Applications of natural products in the control of mosquito-transmitted diseases. Afr J Biotech 8:73737378.

Hooper DC (2001). Mechanisms of action of antimicrobials: focus on fluoroquinolones. Clin Infect Dis 32: S9-S35.

Houbraken J, Frisvad JC, Samson RA (2011). Fleming's penicillin producing strain is not Penicillium chrysogenum but $P$. rubens. IMA Fungus 2(1): 87-95.

Jaradat ZW, Bhunia AK (2002). Glucose and nutrient concentrations affect the expression of a 104-kilodalton Listeria adhesion protein in Listeria monocytogenes. Appl Environ Microbiol 68(10): 4876-4883.

Jeganathan P, Rajasekaran KM, Devi NKA, Karuppusamy S (2013). Antimicrobial activity and characterization of marine bacteria. Indian $J$ Pharm Biol Res 1(4): 38-44.

Joseph B, Dhas B, Hena V, Raj J (2013). Bacteriocin from Bacillus subtilis as a novel drug against diabetic foot ulcer bacterial pathogens. Asian Pac J Trop Biomed 3(12): 942-946.

Mani C, Thirugnanasambatham K, Sundarapandian S, Poopathi $S$ (2015). Identification and characterization of a novel marine Bacillus cereus VCRC-B540 for mosquito control. BioControl 60: 71 79.

Marinho PR, Moreira APB, Pellegrino FLPC, Muricy G (2009). Marine Pseudomonas putida: a potential source of antimicrobia substances against antibiotic-resistant bacteria. Memorias do Instituto Oswaldo Cruz 104(5): 678-682.

Meyer BN, Ferrigni NR, Putnam JE, Jacobsen LB, Nichols DE, McLaughlin JL (1982). Brine shrimp: a convenient general bioassay for active plants constituents. Plant Med 45: 31-34.

Murray PR, Zaitinger JR (1983). Evaluation of mueller-hinton agar for disk diffusion susceptibility test. J Clin Microbiol 18(5): 12691271.

Nabar BM, Lokegaonkar S (2015). Larvicidal activity of microbial metabolites extracted from extremophiles against vector mosquitoes. IJMR 2(3): 161-165.
Nweze El, Mukherjee PK, Ghannoum MA (2010). Agar-based disk diffusion assay for susceptibility testing of dermatophytes. J Clin Microbiol 48(10): 3750-3752.

Odeyemi AT, Ajayi AO, Igbalajobi OA (2013). Plasmid profile of isolated bacteria from Arinta Waterfall in Ipole-lloro Ekiti. J Microbiol Res $3(1): 32-28$.

Olowa LF, Nuneza OM (2013). Brine shrimp lethality assay of the ethanolic extracts of three selected species of medicinal plants from Iligan City, Philippines. Int Res J Biological Sci 2(11): 74-77.

Pandey A, Malviya T (2014). Production of antibiotics isolated from soil bacteria from rhizosperic and non-rhizoperic region of medicinal plants. Indian J Appl Res 4(8): 25-32.

Plaza GA, Turek A, Krol E, Szczyglowska R (2013). Antifungal and antibacterial properties of surfactin isolated from Bacillus subtilis growing on molasses. Afr J Microbiol Res 7(25): 3165-3170.

Priest FG (1992). A review: biological control of mosquitoes and other biting flies by Bacillus sphaericus and Bacillus thuringiensis. J Appl Bacteriol 72:357-369.

Pundir RK, Rana S, Kashyap N, Kaur A (2013). Probiotic potential of lactic acid bacteria isolated from food samples: an in vitro study. JAPS 3(3): 085-093.

Sharma A, Diwevidi VD, Singh S, Pawar KK, Jerman M, Singh LB, Singh S, Srivastawa D (2013). Biological control and its imporant in agiculture. IJBBR 4(3): 175-180.

Shetty PR, Buddana SK, Tatipamula VB, Naga YVV, Ahmad J (2014). Production of polypeptide antibiotic from Streptomyces parvulus and its antibacterial activity. Braz J Microbiol 45(1): 303-312.

Silhavy TJ, Kahne D, Walker S (2010). The bacterial cell envelope. Cold Spring Harb Perspect Biol 2: a000414.

Soni K (2012). Fluoroquinolones: chemistry and action - a review. Indo Global J Pharm Sciences 2(1): 43-53.

Sunder J, Jeyakumar SS, Kundu A, De AK (2011). Antibacterial activity in solvent extract of different parts of Morinda citrifolia plant. $J$ Pharm Sci Res 3(8): 1404-1407.

Veronica, Lay BW, Magdalena S (2014). Isolation and characterization of new antibiotics from Indonesian coastal marine bacteria. Microbiol Indones 8(3): 87-93.

Wu C (2014). An important player in brine shrimp lethality bioassay: the solvent. J Adv Pharm Technol Res 5(1): 57 - 58. 